Effects of Spinal Mobilisations on Lumbar and Hamstring ROM and sEMG: A Randomised

\title{
Control Trial
}

Paul Chesterton *, Stephen Payton

Sport and Exercise Science Section, Teesside University, Middlesbrough, United Kingdom

Corresponding author:

*Paul Chesterton

Sport and Exercise Science Section,

Teesside University, Middlesbrough, United Kingdom

e-mail: p.chesterton@tees.ac.uk

Tel.: +44 (0) 1642348246

Word Count for text only: 2,838

No funding was received for this trial. 


\begin{abstract}
Introduction: This study aimed to compare the immediate effects of Posterior Anterior (PA) L4 and L5 mobilisations on range of motion and muscle activity measures in the lumbar and hamstring regions of asymptomatic individuals.
\end{abstract}

Methods: Thirty-eight participants were randomly allocated to a mobilisation $(n=20)$ or control $(n=18)$ group. The mobilisation group received central PA mobilisations to the L4 and L5 vertebrae, three times for two minutes. The control group received no mobilisation. Pre- and post-test measures included lumbar range of motion, measured by the modified Schober test and hamstring extensibility by the active knee extension test. Local Erector Spinae and Biceps Femoris muscle activation were also measured by surface Electromyography. Data were analysed using magnitude-based inferences.

Results: Lumbar mobilisations had a most likely beneficial effect on active lumbar flexion $18.6 \%$ $(90 \%$ CL $11.8 \% \pm 25.8 \%)$ and active knee extension range $22.8 \%(-29.6 \% \pm 15.2 \%)$. Mobilisations had a possible beneficial effect in SEMG activation reduction of the Erector Spinae $-4.7 \%(-10.5 \% \pm$ 1.4\%) and Bicep Femoris $-6.1 \%(-13.1 \% \pm 1.6 \%)$ during lumbar flexion. Likely beneficial effects of reduced sEMG were found following mobilisations during the active knee extension test for the Erector Spinae $-18.3 \%(-27.7 \%-7.6 \%)$ and Biceps Femoris muscle activity $-20.8 \%(-30.9 \% \pm 9.2 \%)$.

Discussion: L4 and L5 mobilisations increase lumbar and hamstring range of motion in the immediate term. Our unique finding was that, in this sample population, muscle activity in both local Erector Spinae and Biceps Femoris reduced, most likely due to the mobilisations applied.

Key Words: Lumbar, Hamstrings, Mobilisations, sEMG 


\section{INTRODUCTION}

Hamstring strains are one of the most common musculoskeletal injuries suffered within high-intensity intermittent sports ${ }^{[1-3]}$. The rehabilitation of hamstring strains continues to be problematic with no universally accepted rehabilitation programme; however the lumbar spine has been suggested as a pertinent area to treat as part of a multifactorial approach ${ }^{[4-7]}$. Evidence exists to support the efficacy of lumbar mobilisations to reduce spinal pain and restore mobility ${ }^{[8-12]}$. Furthermore, PA (Posterior Anterior) mobilisations have also produced increases in posterior chain neurodynamics and hamstring extensibility in a general population ${ }^{[13-14]}$ and elite footballers ${ }^{[15]}$. This provides some evidence for the lumbar spine's ability to influence the hamstring complex.

Despite spinal mobilisations improving posterior neurodynamics, the mechanism of how this conservative treatment affects hamstring muscle activity has yet to be investigated. Neurophysiological responses to mobilisations have been suggested to involve centrally-mediated processes ${ }^{[16-19]}$. Research has focused on local muscle changes following PA mobilisations with Krekoukias et al ${ }^{[22]}$ reporting reductions in the average sEMG (surface Electromyography) activity of the lumbar erector spinae. Taylor et al ${ }^{[23]}$ and Sterling et al ${ }^{[24]}$ have all reported decreased local muscular activity following central mobilisations. The metabolic activity within the hamstring complex is higher post hamstring injury compared to a non-injured control ${ }^{[25]}$. However, the ability for lumbar mobilisations to decrease the activity of distal muscle groups such as the hamstring complex has yet to be investigated.

Lumbar mobilisations may offer the clinician a method of treating the hamstring group indirectly, in the acute injury stage, where traditional rehabilitation techniques including strength training and flexibility are restricted due to local tissue pathology ${ }^{[26-27]}$.Accordingly, due to the current lack of evidence, the aim of our study was to investigate and quantify the potential effect of central PA lumbar mobilisations on active lumbar flexion range, hamstring extensibility and surface electromyography activity of the Erector Spinae and Biceps Femoris. 


\section{METHODOLOGY}

\section{$\underline{\text { Population }}$}

An original population of forty-five participants were recruited from staff and students at Teesside University, United Kingdom. Recruitment took place between May 2014-February 2015. Table 1 displays the sample descriptions of both testing groups.

$\underline{\text { Table } 1 \text { - Description statistics for intervention and control groups }}$

'Insert Table 1 Here'

Participants were included if they were aged over eighteen, without current spinal or lower limb pathology. All participants were required to complete a medical questionnaire prior to testing. Exclusion criteria included current symptomatic low back pain, hamstring or hip pathology. Previous neurological disorders or current neurological symptoms also prevented inclusion. A history of lumbar surgery or any contraindication to spinal mobilisation prevented participation ${ }^{[28]}$. Following screening thirty-eight participants were eligible for inclusion. The study was granted ethical approval from Teesside University Research Ethics Committee (SSSBLREC230616).

\section{$\underline{\text { Protocol }}$}

This study involved a randomised controlled trial pre-test/post-test parallel groups design to investigate the effects of central PA lumbar mobilisations on measures of lumbar and hamstring range of motion and muscle activity. This reporting will follow recommendations from CONSORT for publishing non-pharmacologic intervention studies ${ }^{[29]}$. Participants were electronically randomised by concealed allocation to the intervention or control groups, via a blind assessor, without restriction to replicate clinical practice. Outcome measures taken at initial assessment included active lumbar flexion (ALF), active knee extension (AKE) and sEMG of the Erector Spinae and Biceps Femoris. All outcome measures were recorded by an assessor blinded to group allocation. sEMG during ALF and AKE were recorded together with resting potential. The order of the ALF and AKE were 
counterbalanced to prevent the order of assessment adversely influencing measurements. The study took place within a biomedical sciences laboratory at Teesside University at same time of day preventing diurnal differences.

\section{Pre-conditioning}

A pilot study conducted with six participants reported four ALF and AKE were required to counteract against variations in tissue extensibility ${ }^{[30-31]}$. The final ROM (range of motion) on the $4^{\text {th }}$ repetition was recorded as the pre-intervention measurement. A 20-min period was required for the clinician to explain, identify and perform lumbar mobilisations prior to re-testing.

\section{Lumbar Mobilisations}

Participants allocated to the intervention group received central PA lumbar mobilisations to the L4 and L5 vertebrae segments. Participants lay prone on a plinth which was placed upon two force plates measuring the mobilisation force. The force applied during the mobilisation protocol was an average force of $104.18 \mathrm{~N} \pm 11.2$ in line with previous studies for a grade three PA mobilisation ${ }^{[22]}$. Grade three mobilisations were applied to the intervention group by a physiotherapist with 9 years' clinical experience and postgraduate manual therapy qualifications. The mobilisation was performed for two

minutes, three times alternating between L4 and L5, without rest in between ${ }^{[28,32]}$. Each vertebra level was determined by the palpation of relevant spinous processes and passive physiological intervertebral movement. The mobilisations were applied at a frequency of $1 \mathrm{~Hz}$ maintained by a metronome. Force plate data was recorded at $500 \mathrm{~Hz}$ above the frequency of the mobilisations preventing sampling errors.

The control group following pre-measurement lay in prone on a plinth for the twenty minute interval determined by the pre-conditioning study. Post intervention and control ALF and AKE were reassessed immediately via a single test with measurements taken. The reassessment process took approximately three minutes per participant.

\section{$\underline{\text { Active Lumbar Flexion Measurement }}$}


The modified Schober (mSchober) test was performed to measure lumbar flexion. The mSchober test has been reported to obtain high reliability and has been recommended as an appropriate clinical evaluation tool of lumbar spinal motion ${ }^{[33-34]}$. The mSchober test was performed with the participant standing on a wooden box $60 \mathrm{~cm}$ in height with feet positioned $8 \mathrm{~cm}$ apart indicated by tape. The lead researcher, via a skin marker, identified one point $5 \mathrm{~cm}$ below and one point $10 \mathrm{~cm}$ above the lumbosacral junction, determined by a passive physiological intervertebral movement $[28,34]$. Participants were instructed to actively flex forward as far as possible, whilst keeping the knees extended, and to maintain this position until instructed to return to neutral. The distance between the two skin marks was measured by a tape measure (seca Germany) in centimeters pre and post-test with the difference recorded as the range of lumbar flexion.

\section{$\underline{\text { Active Knee Extension Measurement }}$}

Active hamstring extensibility of the dominant leg determined by kicking foot was assessed via the AKE test, a reliable method of measuring hamstring tissue extensibility ${ }^{[35-37]}$. Participants lay supine on a padded plinth secured by a 5 centimeter mobilisation belt placed across the anterior superior iliac spine. Another mobilisation belt was placed 20 centimeters above the tibial tuberosity preventing motion of the non-dominant/testing leg ${ }^{[38]}$. The belt positions were marked for re-measurement purposes. A purpose made wooden wedge provided a right angle surface to ensure the hip was supported at 90 degrees. Hamstring extensibility was tested till the end of maximal range determined by the participant and was acknowledged by a manual trigger ${ }^{[39]}$. An inclinometer (Dr Rippstein, Zurich, Switzerland) recorded positional change and was placed on the anterior tibial border midway between the inferior pole of the patella and the line between the malleoli ${ }^{[40]}$.The ankle was maintained in plantigrade by a medical brace.

\section{EMG Application}

sEMG of the Bicep Femoris and Erector Spine was recorded on the participant's dominant side. As the most common hamstring tendon injured, Biceps Femoris, was chosen for EMG application ${ }^{[41]}$. 
These superficial muscles provide an accurate recording, clearer signals and reduce potential issues with sEMG cross talk ${ }^{[42]}$. sEMG was recorded for 10 seconds at rest pre and post intervention in prone, at end range of ALF and AKE pre and post intervention and control. Average values for the 10 seconds were used for analysis. Recording in a static position eliminated any movement artefact noise originating at the electrode-skin interface.

Prior to the bipolar electrode application the area of skin was shaved and cleaned with a $70 \%$ isopropyl alcohol wipe. Noraxon, self-adhesive $\mathrm{Ag} / \mathrm{AgCl}$ snap electrodes (Noraxon USA) were then applied providing a stable transition with low noise ${ }^{[43]}$. Noraxon electrodes have an inter electrode space of $20 \mathrm{~mm}$ and were placed on the relevant muscle tissue in accordance to Seniam recommendations ${ }^{[43]}$. The position of the electrode for the Erector Spinae (longissimus) was placed two finger widths lateral to L1. The electrode for the Biceps Femoris was placed on the line half way between the ischial tuberosity and the lateral epicondyle of the tibia. Electrodes remained in position throughout the testing procedure minimising potential electrode placement error.

\section{EMG Data Collection and Filter}

The sEMG was recorded at $2000 \mathrm{~Hz}$ using the Cometa wave wireless EMG system. The A/D data logger converted the collected data at $2000 \mathrm{HZ}$ for each intervention. The sEMG signal was processed and filtered using Cometa v1.6 software. The data was processed using a high pass Butterworth filter with a cut off frequency of $20 \mathrm{~Hz}^{[43-45]}$.

The data was rectified and smoothed using a RMS filter with a floating window of $20 \mathrm{~ms}{ }^{[22,46,47]}$. The zero wire system eliminated any cable motion artefacts that could contaminate the sEMG signal. This study compared low level sEMG data, which is inherently unstable, and therefore no Maximum Voluntary Contraction (MVC) was recorded. Recording MVC would have increased muscle activity potentially influencing data recorded at rest, during ALF and AKE ${ }^{[48]}$. Within a data collection session where no individual changes to the configuration of the EMG set-up (electrode placement, amplification, filtering) has taken place and whilst under constant temperature and humidity conditions EMG data does not need to be normalised against a MVC to be interpreted ${ }^{[49-50]}$. 


\section{$\underline{\text { Statistical Analysis }}$}

Raw data is presented as the mean $\pm \mathrm{SD}$. Before analysis, data were log transformed and then back transformed to obtain the difference between lumbar flexion range, hamstring extensibility and sEMG of the lumbar extensors and Bicep Femoris as accurate percentages. This method also reduced the error rising from non-uniform residuals. The use of the $\mathrm{P}$ value alone fails to provide information about the direction, effect size or the range of feasible values ${ }^{[51]}$. We therefore used the magnitudebased inference approach to examine the range of motion change in the lumbar spine and hamstring, sEMG activity in the local lumbar extensors and biceps femoris following PA lumbar mobilisations. Effect sizes of 0.2, 0.6, and 1.2 multiplied by the pooled between-participant SD were considered small, moderate and large, respectively ${ }^{[52]}$, with uncertainty of the estimates shown as $90 \%$ confidence intervals. Subsequently, inference was based on the disposition of the confidence interval for the mean difference to this smallest worthwhile effect $(0.2$ of the between-subject SD); the probability (percent chances) that the true population difference between pre- and post-test, and also the pre-post intervention-control difference is substantial ( $>$ smallest worthwhile effect) or trivial was calculated as per the magnitude-based inference approach ${ }^{[53]}$. These percent chances were qualified via probabilistic terms assigned using the following scale: $0.5 \%$, most unlikely or almost certainly not; $0.5-5 \%$, very unlikely; $5-25 \%$, unlikely or probably not; $25-75 \%$, possibly; $75-95 \%$, likely or probably; $95-99.5 \%$, very likely; and $.99 .5 \%$, most likely or almost certainly ${ }^{[54]}$. Inferences were categorised as clinical, with the default probabilities for declaring an effect clinically beneficial being $<0.5 \%$ (most unlikely) for harm and $>25 \%$ (possibly) for benefit. All data were analyzed using a custom-made spread sheet ${ }^{[53]}$.

\section{RESULTS}

The baseline outcome measures, along with effect statistics and inferences for the within- and between-treatment comparisons are presented in Table 2. Outcome measures were obtained from all thirty-eight participants. After controlling for baseline imbalances and test order, the 
application of lumbar mobilisations had a most likely beneficial effect on active lumbar flexion 18.6\% $(90 \%$ CL $11.8 \% \pm 25.8 \%)$ and active knee extension range $22.8 \%(-29.6 \% \pm 15.2 \%)$.

During ALF mobilisations had a possible beneficial effect of reduction in sEMG activation of the Erector Spinae $-4.7 \%(-10.5 \% \pm 1.4 \%)$ and Bicep Femoris $-6.1 \%(-13.1 \% \pm 1.6 \%)$ when directly compared to the control condition. Likely beneficial effects were found following the intervention in sEMG during the AKE for the Erector Spinae $-18.3 \%(-27.7 \%-7.6 \%)$ and Biceps Femoris muscle activity $-20.8 \%(-30.9 \% \pm 9.2 \%)$. No harm or unintended effects were reported.

Table 2 - Outcome measures at baseline with effect statistics and inferences for within- and $\underline{\text { between-group comparisons }}$

'Insert Table 2 Here'

\section{DISCUSSION}

The effective treatment of the hamstring region continues to be one of the most difficult within sports medicine. Lumbar spine mobilisations are a conservative technique used by clinicians to treat not only the lumbar region but the hamstring complex, despite a lack of evidence to support its effectiveness. Therefore, this randomised control trial aimed to investigate the effects of central PA lumbar mobilisations on range of motion and muscle activation of the Erector Spinae and Biceps Femoris. PA mobilisations had a likely beneficial increase in range of motion in the ALF and AKE tests. Following L4 and L5 mobilisations a possible beneficial effect on the reduction of sEMG activity of the Erector Spinae and Biceps Femoris was reported compared to the control. A likely beneficial effect in the reduction of both the Erector Spinae and Biceps Femoris occurred during the AKE test following the intervention. Accordingly, this is the first study of its kind to report changes in the ROM and sEMG activity of both the Lumbar and Hamstring following spinal mobilisations. 
A key and unique finding of this study is the beneficial effect of central PA L4 and L5 mobilisations on hamstring range and Biceps Femoris sEMG activity. Chesterton et al ${ }^{[15]}$ reported an increase in hamstring range following spinal mobilisations; however the underlying mechanisms were not investigated. This study suggests that range increases in the hamstring are also associated with sEMG activity reduction. Local reduction in sEMG has been observed by Krekoukias et al ${ }^{[22]}$ and Pentelka et ${ }^{\text {al }}{ }^{[54]}$ in the Erector Spinae following PA mobilisations to the lumbar region. Both studies findings are consistent with findings following mobilisations to the temporomandibular joint ${ }^{[23]}$ and the cervical spine ${ }^{[24]}$. sEMG reduction in these studies have been linked to decreased associated pain and increased range of motion. Perry and Green ${ }^{[55]}$ concluded that unilateral lumbar mobilisations result in side-specific peripheral sympathetic nervous system changes. Therefore, neurophysiological and anatomical inter-relationships within the lumbar spine exist and can by externally modulated through the application of mobilisation.

A number of mechanisms for this sEMG reduction have been described previously within the literature. Following passive mobilisations muscle spindle activity may increase, stimulating golgitendon organ activity and in turn produce a muscle reflex inhibition ${ }^{[56-58]}$. A hypoalgesic response has also been found following mobilisation to the cervical spine ${ }^{[24,59-61]}$, the knee ${ }^{[62]}$ and shoulder ${ }^{[63] \text {. }}$ This study suggests these changes may be found in the hamstring following PA lumbar mobilisations.

These results provide clinicians with a clearer understanding of the effect mobilising the lumbar spine has on the hamstring muscle group. Despite this asymptomatic population this type of conservative technique has the potential to be employed as part of a wider holistic approach to hamstring management. Clinicians have been advised to account for complex neuromuscular mechanisms within the hamstring complex, with the quantity of hamstring muscle activation and recruitment critical to injury risk ${ }^{[25] .}$ Increased activation has been linked to hamstring injury causing premature fatigue. Therefore, decreasing muscle activity and increasing extensibility, may have a role in prevention and rehabilitation, especially in the lumbar related hamstring described by Orchard et al ${ }^{[64]}$. 
Furthermore, this study also suggests L4 and L5 central PA mobilisations have the ability to increase spinal ROM in the immediate term. These results are in contrast to Petty ${ }^{[65]}$, Chiradejnant et al ${ }^{[66-67]}$ and Stamos-Papastamos et al, ${ }^{[32]}$ who all found no significant effect of lumbar mobilisations on range of motion. However, both Powers et al ${ }^{[68]}$ and McCollam and Benson ${ }^{[69]}$ both have reported increases in $\mathrm{ROM}$ post mobilisation. Powers ${ }^{[68]}$ reported an average increase of $17.8 \%$ compared to $7.1 \%$ by McCollam and Benson ${ }^{[69]}$. The actual range required to be deemed clinically significant has yet to be identified but importantly all studies do not have a follow-up to understand the treatments longevity. The current study differs in intervention dose from Powers ${ }^{[68]}$, two minute spinal mobilisations at one vertebral level, and McCollam and Benson ${ }^{[69]}$, three one minute applications at L3, L4 and L5. The vast number of variables including study design, technique, grade, dose and level of mobilisation mean that study comparison is difficult. At least one key differing variable is found within each design, and careful consideration of methodology is required for future studies to allow direct comparison.

\section{Limitations and Future Research}

This study was conducted on asymptomatic participants and therefore the ability for lumbar PA mobilisations to influence the ROM and sEMG activity of symptomatic individuals remains unknown. Only immediate effects were investigated due to the study objectives and therefore conclusions of the short and medium term effects of the intervention are unidentified. These limitations in themselves pave the way for future research on mobilisations assessed in symptomatic participants across short, medium and long-term timeframes. Optimal dose, grade and level of mobilisation need further research for a deeper understanding of how lumbar mobilisations may support hamstring management. The study was not powered and therefore it is appropriate to interpret the conclusions generated with this understanding. The application of sEMG itself has limitations. The quality of sEMG signal can be affected by external noise, the pickup of electrical activity of adjacent muscle, the amount of active motor units at the time of recording and the depth of adipose tissue the signal has to travel through ${ }^{[70]}$. 


\section{$\underline{\text { Implications }}$}

Mobilisations continue to form part of the management of patients with lumbar spine and hamstring pathology. The results of this study suggest PA lumbar mobilisations decreased the muscle activity of both the Erector Spinae and Biceps Femoris. Functionally, the mobilisations resulted in an increase of lumbar and hamstring range of motion compared to a control. As part of a multifactorial approach to hamstring management lumbar mobilisations, as a conservative treatment technique, have the capacity to influence the hamstring complex. 


\section{REFERENCES}

1. Brooks JH, Fuller CW, Kemp SP, Reddin DB. Incidence, risk, and prevention of hamstring muscle injuries in professional rugby union. Am J Sports Med. 2006; 34:1297-306.

2. Brughelli M, Cronin J. Preventing hamstring injuries in sport. Strength Cond J. 2008; 30:55-64.

3. Yeung SS, Suen AM, Yeung EW. A prospective cohort study of hamstring injuries in competitive sprinters: preseason muscle imbalance as a possible risk factor. Br J Sports Med 2009; 43:589-94.

4. Goldman EF, Jones DE. Interventions for preventing hamstring injuries. Cochrane Libr. 2010; 1.

5. Mendiguchia J, Alentorn-Geli E, Brughelli M. Hamstring strain injuries: are we heading in the right direction?. . Br J Sports Med. 2012; 46:81-5.

6. Hoskins W, Pollard H. Hamstring injury management—part 2: treatment. Man Ther. 2005; 10:18090.

7. Mason DL, Dickens VA, Vail A. Rehabilitation for hamstring injuries. Cochrane Libr. 2012; 1.

8. Bronfort G, Haas M, Evans RL, Bouter LM. Efficacy of spinal manipulation and mobilization for low back pain and neck pain: a systematic review and best evidence synthesis. Spine J. 2004; 4:33556.

9. Hanrahan S, Van Lunen BL, Tamburello M, Walker ML. The short-term effects of joint mobilizations on acute mechanical low back dysfunction in collegiate athletes. J Athl Train. 2005; 40:88.

10. Powers CM, Beneck GJ, Kulig K, Landel RF, Fredericson M. Effects of a single session of posterior-to-anterior spinal mobilization and press-up exercise on pain response and lumbar spine extension in people with nonspecific low back pain. Phys Ther. 2008; 88:485-93.

11. Schmid A, Brunner F, Wright A, Bachmann LM. Paradigm shift in manual therapy? Evidence for a central nervous system component in the response to passive cervical joint mobilisation. Man Ther. $2008 ; 13: 387-96$.

12. Slaven EJ, Goode AP, Coronado RA, Poole C, Hegedus EJ. The relative effectiveness of segment specific level and non-specific level spinal joint mobilization on pain and range of motion: results of a systematic review and meta-analysis. J Man Manip Ther. 2013; 21:7-17.

13. Szlezak AM, Georgilopoulos P, Bullock-Saxton JE, Steele MC. The immediate effect of unilateral lumbar Z-joint mobilisation on posterior chain neurodynamics: a randomised controlled study. Man Ther. 2011; 16:609-13.

14. Ganesh GS, Mohanty P, Pattnaik SS. The immediate and 24-hour follow-up effect of unilateral lumbar Z-joint mobilisation on posterior chain neurodynamics. J Bodyw Mov Ther. 2015; 19:226-31. 
15. Chesterton P, Weston M, Butler M. The Effect of Mobilising the Lumbar 4/5 Zygapophyseal Joint on Hamstring Extensibility in Elite Soccer Players. International Journal of Physiotherapy and Rehabilitation. 2016.

16. Sluka KA, Skyba DA, Radhakrishnan R, Leeper BJ, Wright A. Joint mobilization reduces hyperalgesia associated with chronic muscle and joint inflammation in rats. J Pain. 2006; 7:602-7.

17. Slaven EJ, Goode AP, Coronado RA, Poole C, Hegedus EJ. The relative effectiveness of segment specific level and non-specific level spinal joint mobilization on pain and range of motion: results of a systematic review and meta-analysis. J Man Manip Ther. 2013; 21:7-17.

18. Bialosky JE, Bishop MD, Price DD, Robinson ME, George SZ. The mechanisms of manual therapy in the treatment of musculoskeletal pain: a comprehensive model. Man Ther. 2009; 14:531-8.

19. Bishop MD, Beneciuk JM, George SZ. Immediate reduction in temporal sensory summation after thoracic spinal manipulation. Spine J. 2011; 11:440-6.

20. Hurley MV, Jones DW, Newham DJ. Arthrogenic quadriceps inhibition and rehabilitation of patients with extensive traumatic knee injuries. Clin Sci. 1994; 86:305-10.

21. Suter E, McMorland G, Herzog W, Bray R. Conservative lower back treatment reduces inhibition in knee-extensor muscles: a randomized controlled trial. J Manipulative Physiol Ther. 2000; 23:76-80.

22. Krekoukias G, Petty NJ, Cheek L. Comparison of surface electromyographic activity of erector spinae before and after the application of central posteroanterior mobilisation on the lumbar spine. $\mathrm{J}$ Electromyogr Kinesiol. 2009; 19:39-45.

23. Taylor M, Suvinen T, Reade P. The effect of grade IV distraction mobilisation on patients with temporomandibular pain-dysfunction disorder. Physiother Theory Pract. 1994; 10:129-36.

24. Sterling M, Jull G, Wright A. Cervical mobilisation: concurrent effects on pain, sympathetic nervous system activity and motor activity. Man Ther. 2001; 6:72-81.

25. Schuermans J, Van Tiggelen D, Danneels L, Witvrouw E. Biceps femoris and semitendinosusteammates or competitors? New insights into hamstring injury mechanisms in male football players: a muscle functional MRI study. British journal of sports medicine. 2014 Dec 1;48(22):1599-606.

26. Witvrouw E, Danneels L, Asselman P, et al. Muscle flexibility as a risk factor for developing muscle injuries in male professional soccer players. A prospective study. Am J Sports Med 2003 ; 31 : $41-6$.

27. Askling C, Saartok T, Thorstensson A. Type of acute hamstring strain affects flexibility, strength, and time to return to pre-injury level. Br J Sports Med $2006 ; 40: 40-4$.

28. Maitland GD. Vertebral manipulation. Butterworth-Heinemann; 2013.

29. Boutron I, Moher D, Altman DG, Schulz KF, Ravaud P. Extending the CONSORT statement to randomized trials of nonpharmacologic treatment: explanation and elaboration. Ann Intern Med.

2008; 148:295-309. 
30. Dixon JK, Keating JL. Variability in straight leg raise measurements: Review. Physiother. 2000; 86:361-70.

31. Lee RY, Munn J. Passive moment about the hip in straight leg raising. Clin Biomech. 2000; $15: 330-4$

32. Stamos-Papastamos N, Petty NJ, Williams JM. Changes in bending stiffness and lumbar spine range of movement following lumbar mobilization and manipulation. J Manipulative Physiol Ther. $2011 ; 34: 46-53$.

33. Strender LE, Sjöblom A, Sundell K, Ludwig R, Taube A. Interexaminer reliability in physical examination of patients with low back pain. Spine. 1997; 22:814-20.

34. Robinson HS, Mengshoel AM. Assessments of lumbar flexion range of motion: intertester reliability and concurrent validity of 2 commonly used clinical tests. Spine. 2014; 39:E270-5.

35. Norris CM, Matthews M. Inter-tester reliability of a self-monitored active knee extension test. J Bodyw Mov Ther. 2005; 9:256-9.

36. Hunter DG, Speed CA. The assessment and management of chronic hamstring/posterior thigh pain. Best Practice \& Research Clin Rheumatol. 2007; 21:261-77.

37. Gnat R, Kuszewski M, Koczar R, Dziewońska A. Reliability of the passive knee flexion and extension tests in healthy subjects. J Manipulative Physiol Ther. 2010; 33:659-65.

38. Farquharson C, Greig M. Temporal efficacy of kinesiology tape vs. Traditional stretching methods on hamstring extensibility. Int J Sports Phys Ther. 2015; 10:45-51.

39. Gajdosik RL, Rieck MA, Sullivan DK, Wightman SE. Comparison of four clinical tests for assessing hamstring muscle length. J Orthop Sports Phys Ther. 1993; 18:614-8.

40. Reurink G, Goudswaard GJ, Oomen HG, Moen MH, Tol JL, Verhaar JA, Weir A. Reliability of the active and passive knee extension test in acute hamstring injuries. Am J Sports Med. 2013; 41:1757-61.

41. Askling CM, Koulouris G, Saartok T, Werner S, Best TM. Total proximal hamstring ruptures: clinical and MRI aspects including guidelines for postoperative rehabilitation. Knee Surgery, Sports Traumatology, Arthroscopy. 2013 Mar 1;21(3):515-33.

42. Hermens HJ, Freriks B, Merletti R, Stegeman D, Blok J, Rau G, Disselhorst-Klug C, Hägg G. European recommendations for surface electromyography. Roessingh Research and Development. 1999; 8:13-54.

43. Stegeman D, Hermens H. Standards for surface electromyography: the European project "Surface EMG for non-invasive assessment of muscles (SENIAM)" 1999

44. Laursen B, Jensen BR, Sjøgaard G. Effect of speed and precision demands on human shoulder muscle electromyography during a repetitive task. Eur J Appl Physiol Occup Physiol. 1998; 78:544-8.

45. De Luca CJ, Gilmore LD, Kuznetsov M, Roy SH. Filtering the surface EMG signal: Movement artifact and baseline noise contamination. J Biomech. 2010; 43:1573-9. 
46. Gerdle B, Henriksson-larsen K, Lorentzon R, Wretling ML. Dependence of the mean power frequency of the electromyogram on muscle force and fibre type. Acta Physiol. 1991; 142:457-65.

47. Bilodeau M, Schindler-Ivens S, Williams DM, Chandran R, Sharma SS. EMG frequency content changes with increasing force and during fatigue in the quadriceps femoris muscle of men and women. J Electromyogr Kinesiol. 2003; 13:83-92.

48. Snijders CJ, Slagter AH, van Strik R, Vleeming A, Stoeckart R, Stam HJ. Why Leg Crossing?: The Influence of Common Postures on Abdominal Muscle Activity. Spine. 1995; 20:1989-93.

49. Erdelyil A, Sihvonen T, Helin P, Hänninen O. Shoulder strain in keyboard workers and its alleviation by arm supports. Int Arch Occup Environ Health. 1988; 60:119-24.

50. Mathiassen SE, Winkel J, Hägg GM. Normalization of surface EMG amplitude from the upper trapezius muscle in ergonomic studies—a review. J Electromyogr Kinesiol. 1995; 5:197-226.

51. Batterham AM, Hopkins WG. Making meaningful inferences about magnitudes. Int J Sports Physiol Perform. 2006; 1.

52. Hopkins W, Marshall S, Batterham A, Hanin J. Progressive statistics for studies in sports medicine and exercise science. Med Sci Sports Exerc. 2009; 41:3.

53. Hopkins WG. A spreadsheet for deriving a confidence interval, mechanistic inference and clinical inference from a P value. Sportscience. 2007; 11:16-21.

54. Pentelka L, Hebron C, Shapleski R, Goldshtein I. The effect of increasing sets (within one treatment session) and different set durations (between treatment sessions) of lumbar spine posteroanterior mobilisations on pressure pain thresholds. Man Ther. 2012; 17:526-30.

55. Perry J, Green A. An investigation into the effects of a unilaterally applied lumbar mobilisation technique on peripheral sympathetic nervous system activity in the lower limbs. Man Ther. 2008; 13:492-9.

56. Lewis GN, Byblow WD, Carson RG. Phasic modulation of corticomotor excitability during passive movement of the upper limb: effects of movement frequency and muscle specificity. Brain Res. 2001; 900:282-94.

57. Dishman JD, Burke J. Spinal reflex excitability changes after cervical and lumbar spinal manipulation: a comparative study. Spine J. 2003; 3:204-12.

58. Bolton PS, Budgell BS. Spinal manipulation and spinal mobilization influence different axial sensory beds. Med. Hypotheses. 2006; 66:258-62.

59. Wright A, Vicenzino B. Cervical mobilisation techniques, sympathetic nervous system effects and their relationship to analgesia. InMoving in on Pain 1995; 164-173

60. Vicenzino B, Collins D, Wright A. The initial effects of a cervical spine manipulative physiotherapy treatment on the pain and dysfunction of lateral epicondylalgia. Pain. 1996; 68:69-74.

61. Vicenzino B, Collins D, Benson H, Wright A. An investigation of the interrelationship between manipulative therapy-induced hypoalgesia and sympathoexcitation. J Manipulative Physiol Ther. 1998; 21:448-53. 
62. Moss P, Sluka K, Wright A. The initial effects of knee joint mobilization on osteoarthritic hyperalgesia. Man Ther. 2007; 12:109-18.

63. Teys P, Bisset L, Vicenzino B. The initial effects of a Mulligan's mobilization with movement technique on range of movement and pressure pain threshold in pain-limited shoulders. Man Ther. 2008; 13(1):37-42.

64. Orchard JW, Farhart P, Leopold C. Lumbar spine region pathology and hamstring and calf injuries in athletes: is there a connection?. British Journal of Sports Medicine. 2004; Aug 1;38(4):502-4.

65. Petty NJ. The effect of posteroanterior mobilisation on sagittal mobility of the lumbar spine. Manual therapy. 1995; 1:25-9.

66. Chiradejnant A, Latimer J, Maher CG, Stepkovitch N. Does the choice of spinal level treated during posteroanterior (PA) mobilisation affect treatment outcome?. Physiother Theory Pract. 2002; 18:165-74.

67. Chiradejnant A, Maher CG, Latimer J, Stepkovitch N. Efficacy of "therapist-selected" versus "randomly selected" mobilisation techniques for the treatment of low back pain: a randomised controlled trial. J Physiother. 2003; 49:233-41.

68. Powers CM, Beneck GJ, Kulig K, Landel RF, Fredericson M. Effects of a single session of posterior-to-anterior spinal mobilization and press-up exercise on pain response and lumbar spine extension in people with nonspecific low back pain. Phys Ther. 2008; 88:485-93

69. McCollam RL, Benson CJ. Effects of postero-anterior mobilization on lumbar extension and flexion. J Man Manip Ther 2013; 18.

70. Kuiken TA, Lowery MM, Stoykov NS. The effect of subcutaneous fat on myoelectric signal amplitude and cross-talk. Prosthet Orthot Int. 2003; 27:48-54. 
Table 1 - Description statistics for intervention and control groups

\begin{tabular}{lcc}
\hline & $\begin{array}{c}\text { Intervention Group } \\
(\mathbf{n}=\mathbf{2 0})\end{array}$ & $\begin{array}{c}\text { Control Group } \\
(\mathbf{n}=\mathbf{1 8})\end{array}$ \\
\hline Mean \pm SD & Mean \pm SD \\
\hline Age (years) & $3 \pm 11$ & $27.1 \pm 4.09$ \\
Height (cm) & $172 \pm 13$ & $173.1 \pm 9.9$ \\
Body Mass (kg) & $71 \pm 15$ & $72 \pm 18$ \\
\hline
\end{tabular}


Table 2 - Outcome measures at baseline with effect statistics and inferences for within- and between-group comparisons

\begin{tabular}{|c|c|c|c|c|c|c|c|c|}
\hline \multirow[b]{3}{*}{ Outcome Measure } & \multicolumn{6}{|c|}{ Within-Group Changes } & \multirow{2}{*}{\multicolumn{2}{|c|}{$\begin{array}{c}\text { Between-Group } \\
\text { (intervention-control) } \\
\text { Differences } \\
\end{array}$}} \\
\hline & \multicolumn{3}{|c|}{ Mobilization $(\mathbf{n}=\mathbf{2 0})$} & \multicolumn{3}{|c|}{ Control $(n=18)$} & & \\
\hline & $\begin{array}{c}\text { Baseline } \\
\text { values } \\
(\text { mean } \pm \text { SD) }\end{array}$ & $\begin{array}{l}\text { Change score } \\
\text { (\% mean; } \\
\pm 90 \% \mathrm{CL})\end{array}$ & $\begin{array}{l}\text { Qualitative } \\
\text { inference }\end{array}$ & $\begin{array}{c}\text { Baseline } \\
\text { values } \\
(\text { mean } \pm \text { SD) }\end{array}$ & $\begin{array}{l}\text { Change score } \\
\text { (\% mean; } \\
\pm 90 \% \mathrm{CL})\end{array}$ & $\begin{array}{l}\text { Qualitative } \\
\text { inference }\end{array}$ & $\begin{array}{l}\text { Change score } \\
\text { (\% mean; } \\
\pm 90 \% \text { CL })\end{array}$ & $\begin{array}{l}\text { Qualitative } \\
\text { inference }\end{array}$ \\
\hline ALF ROM & $5.69 \pm 1.31$ & $18.3 \pm 6$ & $\begin{array}{l}\text { Small Effect; } \\
\text { Mostly likely } \\
\text { Beneficial }\end{array}$ & $6.01 \pm 1.79$ & $0.3 \pm 1.1$ & $\begin{array}{l}\text { Small effect; } \\
\text { Most Likely } \\
\text { Trivial }\end{array}$ & $\begin{array}{c}18.6(11.8 \pm \\
25.8)\end{array}$ & $\begin{array}{l}\text { Large Effect; } \\
\text { Likely } \\
\text { Beneficial }\end{array}$ \\
\hline $\begin{array}{l}\text { ALF EMG Erector } \\
\text { Spinae }\end{array}$ & $5.56 \pm 1.12$ & $-5.3 \pm 0.8$ & $\begin{array}{l}\text { Small Effect; } \\
\text { Likely } \\
\text { Beneficial }\end{array}$ & $6.76 \pm 2.55$ & $-0.6 \pm 0.3$ & $\begin{array}{l}\text { Small effect; } \\
\text { Most likely } \\
\text { Trivial }\end{array}$ & $\begin{array}{c}-4.7(-10.5 \pm \\
1.4)\end{array}$ & $\begin{array}{l}\text { Moderate } \\
\text { Effect; } \\
\text { Possible } \\
\text { Beneficial }\end{array}$ \\
\hline $\begin{array}{l}\text { ALF EMG Bicep } \\
\text { Femoris }\end{array}$ & $5.82 \pm 1.52$ & $-4.3 \pm 7.9$ & $\begin{array}{l}\text { Large Effect; } \\
\text { Likely } \\
\text { Beneficial }\end{array}$ & $5.69 \pm 2.1$ & $1.9 \pm 1.7$ & $\begin{array}{l}\text { Small Effect; } \\
\text { Most Likely } \\
\text { trivial }\end{array}$ & $\begin{array}{c}-6.1(-13.1 \\
1.6)\end{array}$ & $\begin{array}{l}\text { Small Effect; } \\
\text { Possible } \\
\text { Beneficial }\end{array}$ \\
\hline AKE ROM & $30.9 \pm 10.41$ & $23.2 \pm 9.6$ & $\begin{array}{l}\text { Large Effect; } \\
\text { Likely } \\
\text { Beneficial }\end{array}$ & $33.85 \pm 10.93$ & $-0.6 \pm 1.4$ & $\begin{array}{l}\text { Small Effect; } \\
\text { Most Likely } \\
\text { Trivial }\end{array}$ & $\begin{array}{c}22.8(-29.6 \pm \\
15.2)\end{array}$ & $\begin{array}{l}\text { Large Effect; } \\
\text { Likely } \\
\text { Beneficial }\end{array}$ \\
\hline $\begin{array}{l}\text { AKE EMG } \\
\text { Erector Spinae }\end{array}$ & $7.30 \pm 5.16$ & $16.2 \pm 12.9$ & $\begin{array}{l}\text { Small Effect; } \\
\text { Very Likely } \\
\text { Beneficial }\end{array}$ & $8.47 \pm 4.44$ & $2.6 \pm 2.3$ & $\begin{array}{l}\text { Small Effect } \\
\text { Most Likely } \\
\text { Trivial }\end{array}$ & $\begin{array}{c}-18.3(-27.7 \pm \\
7.6)\end{array}$ & $\begin{array}{l}\text { Small Effect; } \\
\text { Likely } \\
\text { Beneficial- }\end{array}$ \\
\hline $\begin{array}{l}\text { AKE EMG Bicep } \\
\text { Femoris }\end{array}$ & $11.8 \pm 8.21$ & $-21 \pm 14.7$ & $\begin{array}{l}\text { Small Effect; } \\
\text { Likely } \\
\text { Beneficial }\end{array}$ & $11.54 \pm 5.67$ & $-0.3 \pm 0.6$ & $\begin{array}{l}\text { Small Effect } \\
\text { Most Likely } \\
\text { Trivial }\end{array}$ & $\begin{array}{c}-20.8(-30.9 \pm \\
-9.2)\end{array}$ & $\begin{array}{c}\text { Small Effect; } \\
\text { Likely } \\
\text { Beneficial }\end{array}$ \\
\hline
\end{tabular}


